開発途上国における環境影響評価（港湾分野）について

Situation of Environmental Impact Assessment of Port Development Projects in developing countries

堀江 毅 $* 1$
Takeshi HORIE
常山 哲 $* 3$
Satoru TUNEYAMA

\author{
奥 村 研一*2 \\ Ken-ichi OKUMURA \\ 土肥和彦*4 \\ Kazuhiko DOHI
}

ABSTRACT: Situation of the environmental impact assessment (EIA) of port development projects in developing countries was studied through a literature survey and questionnaire/interview to port authorities and relevant organizations/persons, then it was discussed comparing with Japanese EIA system for domestic projects. It appeared that many developing countries had been establishing the EIA law/regulations recently, and more than $80 \%$ of ports of developing countries had implemented the EIA study for their projects. Several characteristics were found in the way of EIA in developing countries comparing with the Japanese system. Selected environmental issues through the scoping procedure are examined in the sequent stages of the project cycle, which formulate the port development plan stepby stepindeveloping countries. Some features of the EIA implementation indeveloping countrieswerepointed out to be aware toconduct a suitable EIA study in compliance with the EIA system in developing countries.

KEYWORDS: ENVIRONMENTAL IMPACT ASSESSMENT, PORT DEVELOMENT PROJECT, EIA LAW/REGULATIONS, ENVIRONMENTAL ITEM, STEP-BY-STEP PROCEDURE

1.はじめに

近年、地球環境に対する関心が高まるなか、1992 年にブラジルのリオデジャネイロで開催 された「地球環境サミット」では「持続可能な開発」という基本理念が新たに世界共通の認 識となり、地球環境保全のための国際協調が重要視されるようになってきた。この背景には、 近年の新興工業国における目覚ましい経済活動の発展により、かつては先進国特有のもので あった環境問題が現在では開発途上国においても深刻なものとなりつつあることがあげられ る。上記サミットでは、開発を自肃して環境保護を重視すべきという「北」の先進国と、開 発を促進して先進国に追いつくべしという「南」の開発途上国との利害関係がぶつかり合う という南北問題が浮き彫りにされた。このような世界状況の下で、「南」の経済自立と発展 に対する「北」の協力も環境配慮への取組みという新しい段階に入っている。

開発途上国への開発援助における環境配虑については、経済開発協力機構 ( OECD) が、 加盟国に対して開発プロジェクトにおける環境配慮の強化を勧告し、具体的な施策、措置の 実施を求めており、それ以来国際的な流れとして定着しつつあるが、環境配慮の具体的な調 查方法、予測手段、保全対策等は現在必ずしも確立していない。

本研究は、こうした状況から、先進国や国際援助機関による環境配虑の実態を把握すると

*1 神戸大学工学部 Kobe University Faculty of Engineering

* 2 運輸省第二港湾建設局京浜港工事事務所 Ministry of Transport The $2^{\text {nd }}$ District Port \& Harbor Construction Bureau Keihin Port Construction Office

*3 新潟県上越土木事務所柿崎川分所 Nigata prefecture Jyoetsu Engineering Bureau Kakizakigawa 0 fice

*4新日本気象海洋株式会社環境情報研究所 Shin-Nippon Meteorologica1 \& 0ceanografical Consultant Co., Ltd Institute of Environmental Informatics 
ともに、開発途上国における環境の現況、環境配虑の実態を分析することにより、開発途上 国において港湾開発プロジェクトを推進する際に必要な環境配慮に関する事項をとりまとめ たものである。

本研究は（財）国際臨海開発研究センターにおいて、平成 5 年度から 3 年にわたり、既 往の文献・資料調查、海外の港湾管理者及びわが国から世界各国に派遣されている港湾分野 の専門家に対するアンケート調查、並びに計 6 回に及ぶ海外現地調查を行い、それらを通し て得られた情報をとりまとめたものである。

\section{2. 環境配慮に関する世界の動向}

環境問題は、世界の各国に抢いて早急に取り組むべき重要課題として認識されている。世 界が環境問題に対処するために用いてきた主要な手段に、条約またはその他のタイプの国際 協定を締結することがある。これまでに 170 余りの環境関連条約が締結されており、このう ち 3 分の 2 以上が 1972 年にストックホルムで開かれた国連人間環境会議後の約 20 年間に成 立している。このことから、近年の環境配慮に関する取り組みは世界的規模で進められてい ることが理解される(図一1)。

また、環境配虑に係わる世界的な動向と して注目すべきことは、特に開発途上国に おいて環境保全のための制度的な枠組み、

ことに、環境影響評価制度が定着しつつあ り、変化しつつあることである。表一 1 は 世界各国の環境影響評価制度の成立を年代 順に示したものである。先進国ではスウェ ーデンや米国をはじめとして 1970 年頃から 環境影響評価制度が整備されている。一方、 開発途上国では、1980年頃から環境影響評 価制度が確立され始め、1990年以降の成立 が目覚ましい。さらに、開発途上国のうち でも特にアジア地域で環境影響評価制度の 定着が著しく、アフリカ地域では遅れてい る傾向がみられる。

わが国の政府開発援助（ODA）における 環境配虑は、相手国の法や制度を遵守する

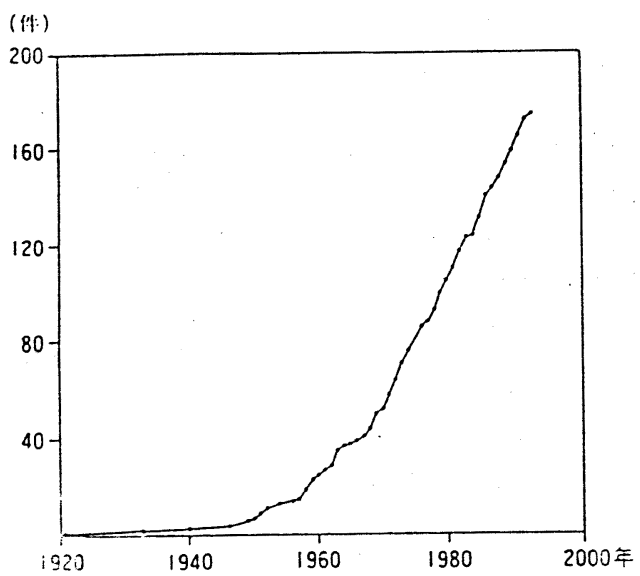

図-1 国際環境条約の件数 (1921-94 年)

出典：「地球白書 1995-96 年」レスター・

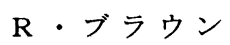

表一 1 環境影響評価制度の根拠法の成立年代

\begin{tabular}{|c|c|c|c|c|}
\hline 1975 年まで & $1976 \sim 1980$ 年 & $1981 \sim 1985$ 年 & $1986 \sim 1990$ 年 & $1991 \sim 1995$ 年 \\
\hline $\begin{array}{c}\text { スウェーデン (1969) } \\
\text { アメリカ }(1970) \\
\text { オーストラリア }\end{array}$ & $\begin{array}{c}\text { フランス }(1976) \\
\text { タ イ }(1978) \\
\text { フィリピン (1978) } \\
\text { 中 国 }(1979)\end{array}$ & $\begin{array}{c}\text { ブラジル(1981) } \\
\text { インドネシア }(1982) \\
\text { スイス }(1983) \\
\text { パキスタン }(1983) \\
\text { マレーシア }\end{array}$ & $\begin{array}{c}\text { イタリア }(1986) \\
\text { インド }(1986) \\
\text { オランダ'(1986) } \\
\text { ギリシア }(1986) \\
\text { スペイン }(1986) \\
\text { ポルトガル }(1987) \\
\text { イギリス }(1988) \\
\text { スリランカ }(1988) \\
\text { メキシコ }(1988) \\
\text { アイルランド(1989) } \\
\text { デンマーク (1989) } \\
\text { 南アフリカ }(1989) \\
\text { 韓 国 }(1990) \\
\text { ルクレブルク (1990) }\end{array}$ & 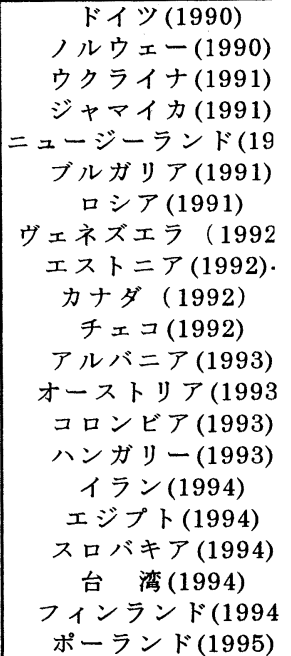 \\
\hline
\end{tabular}

注）わが国においては国としての環境影響評価の根拠法を制定するに至っていない。ただし、 港湾分野においては港湾法（1950年）に基づき環境影響評価が行われている。 
ことを基本的な要件としており、開発途上国におけるこのような変化は、常に注視しておく べき重要な項目である。

港湾分野においても、開発途上国の環境配慮に対する意識の高まりは明らかにみられる。 港湾開発プロジェクトに限定した環境影響評価ガイドラインを作成している国もインド、イ ンドネシア、中国など、アジア地域を中心に出始めており、わが国と同様、分野別のきめ細 かい環境影響評価を実施しょうとする傾向が強まっている。

\section{3. 環境影響 評価実施の動機}

開発途上国の開発プロジェクトにおける環境影響評価の実施状況を世界各国の港湾管理者 に対するアンケート調查により整理した結果では(アンケートに対する回答があったのは 26 力国 31 港湾である)、法的な規定に従って実施するものは全体の半数以下であるが（図一2）、 行政的な措置や融資機関からの要求に従って実施するものを含めると 31 港湾中 25 港湾(約 8 割）の港湾管理者が環境影響評価を実施していることが分かった。

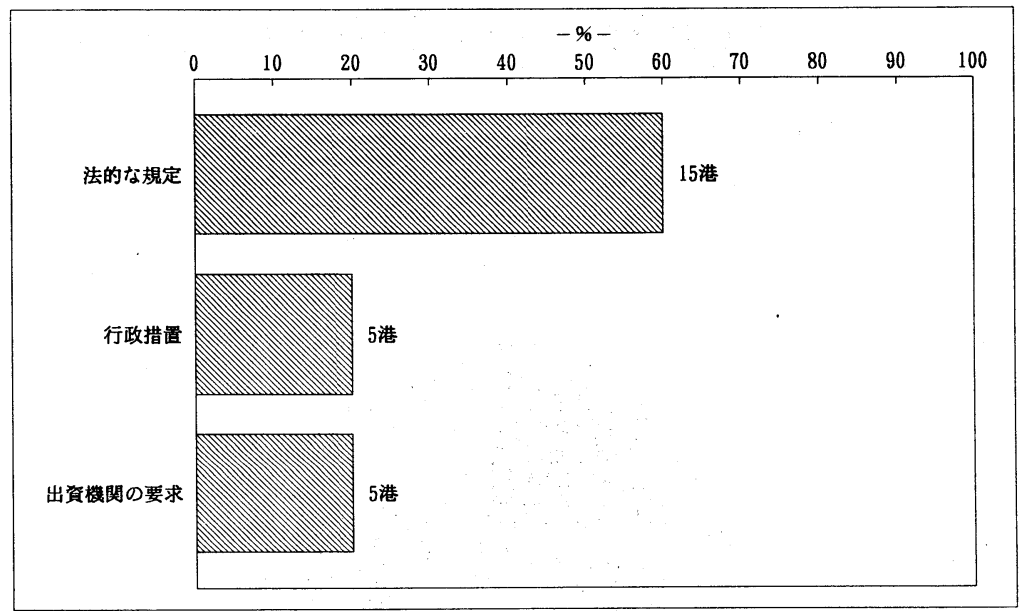

図一 2 港湾開発プロジェクトにおける環境影響評価の必要性

\section{4. 開発途上国における主な環境要因}

港湾環境影響評価において検討すべき環境要因を、前述の港湾管理者に対するアンケート 調查により整理した結果は図ー3のと打りである。回答のあった開発途上国の港湾全体につ いてみると、油等の漏出事故、水質污濁、危険物の取扱いなどが上位を占めている。

アンケート回答を地域別（アジア、アフリカ、中南米、大洋州、中近東、ヨーロッパ）に 区分してみると、前述の 3 つの環境要因（油等の漏出事故、水質污濁、危険物の取扱い）は、 いずれの地域でも上位に挙げられており、地域的な差異は大きくないと考えられた。宗教別 に区分しても同様で、差異は大きくなかった。しかし、図ー4にみられるように、人口稠密 地域（首都あるいはこれに隣接する港湾及び著名な貿易港）では、水質污濁、漏出事故、危 険物の取扱いが多かったのに対し、それ以外の港湾において持水質污濁に代わって生態系へ の影響が強く指摘され、また、社会的インパクトも重要性が高いことが示された。

これらのことから、開発途上国の港湾プロジェクトに打ける環境配虑は、水質污濁、生態 系への影響、社会的インパクト（地域社会文化及び地域社会経済）に加えて、漏出事故や危 険物の取扱いについての検討が期待されていることがわかる。なお、わが国では、漏出事故 や危険物の取扱いは、事業者が、関係する法規制等に従って適切な措置を取ることが義務づ けられており、環境影響評価に打ける環境要因の対象外とされている。また、開発途上国に おいて社会的インパクトのうちでもとくに重要な項目とされる住民移転も、わが国では、計 画そのものの開発地点の選定検討過程において検討済みであり、港湾計画の環境項目として は、通常とりあげていない。

さらに、開発途上国では、その自然環境の特性から、わが国の国内ではなじみの薄いサン ゴ礁、マングローブ等の生態系への影響やシルテーションの問題等、調查・予測手法が確立 
されていない分野も残されている。

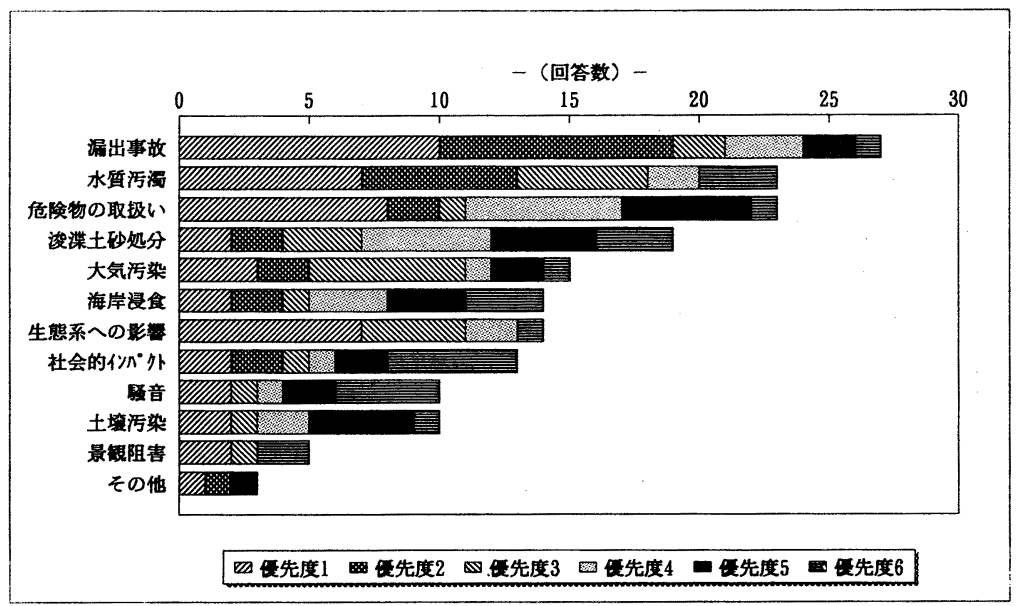

図一 3 港湾の開発及び運営に関わる環境影響評価において検討すべき環境要因
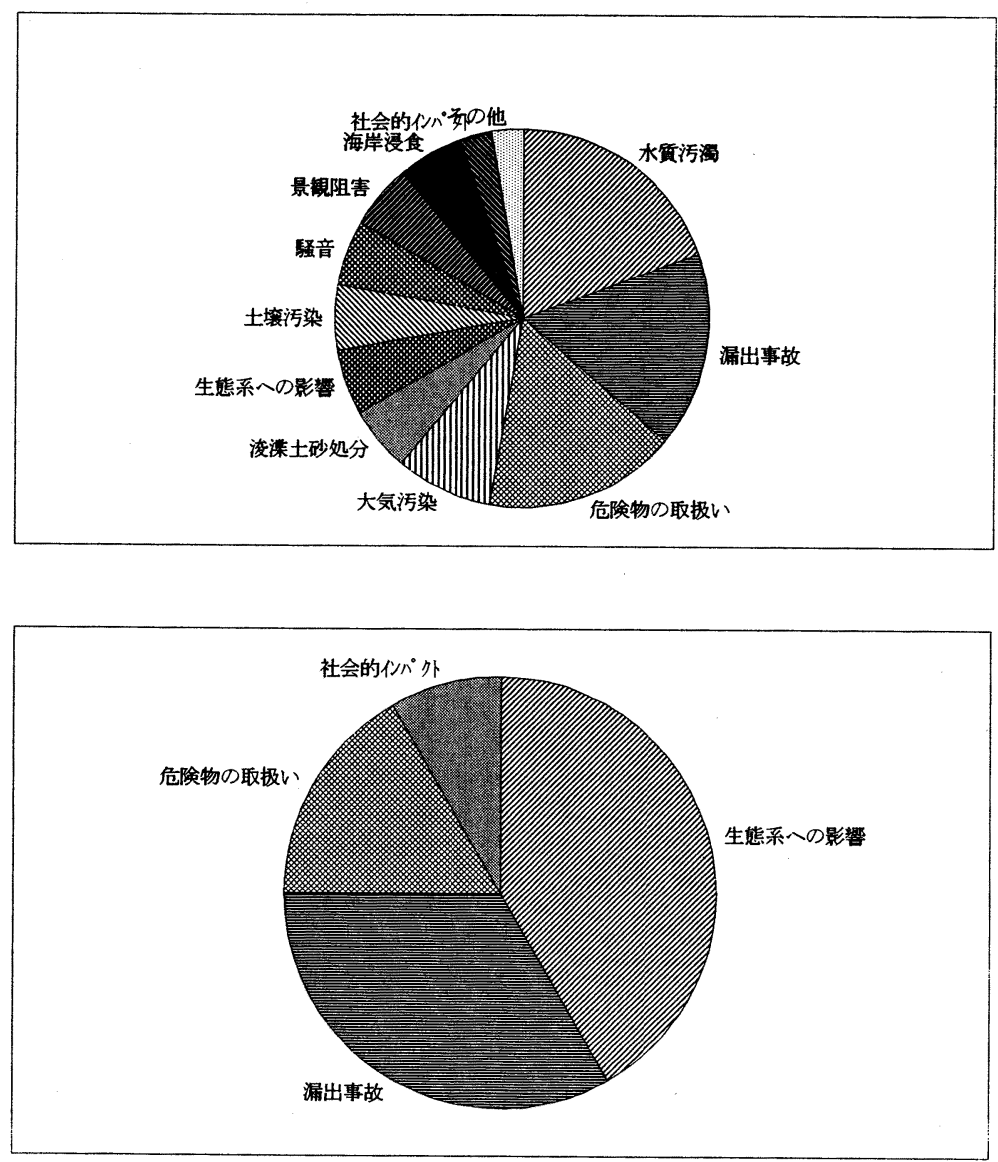

図一 4 港湾開発プロジェクトの環境影響評価において検討すべき最も 優先度の高い環境要因

上：人口稠密地域の港湾（首都あるいはこれに隣接する港湾及 び著名な貿易港)

下：それ以外の港湾 
5 . 開発途上国における環境影響評価の特徵

環境影響評価の考え方は、産業革命後のイギリスをはじめとしてヨーロッパで生まれた。 以前は開発行為のフィージビリティ（企業化適正）を技術的側面と財務 ・ 経済的側面の二面 から評価していたものに加え、環境面からの評価を導入しょうとしたものである。この考え 方は米国等において熟成され、1970年には法体系のもとで実施されるようになった。その後 この手法はアジア地域をはじめ、開発途上国に大きな影響を与えた。

このように、先進国及びその影響を受けた開発途上国の環境影響評価制度は、環境面から のプロジェクト計画の妥当性を計画策定のうちのひとつの部分として取り扱うことから発生 したものである。特に開発途上国においては、プロジェクトを早急に実施し、経済効果を速 やかに発揮させる必要があることから、人材、資金及び環境質データが不足しがちな中で、 計画を熟成させていく各段階において重大な環境影響があり得るか否かを検討し（図一 5 参 照）、それがあると考えられた場合には、計画地点の選定や開発規模など計画そのものまで 立ち戾って变更を強いられることもあり得る。環境影響がないと判断された場合にはその時 点で速やかに計画の実施に移ることが多い。

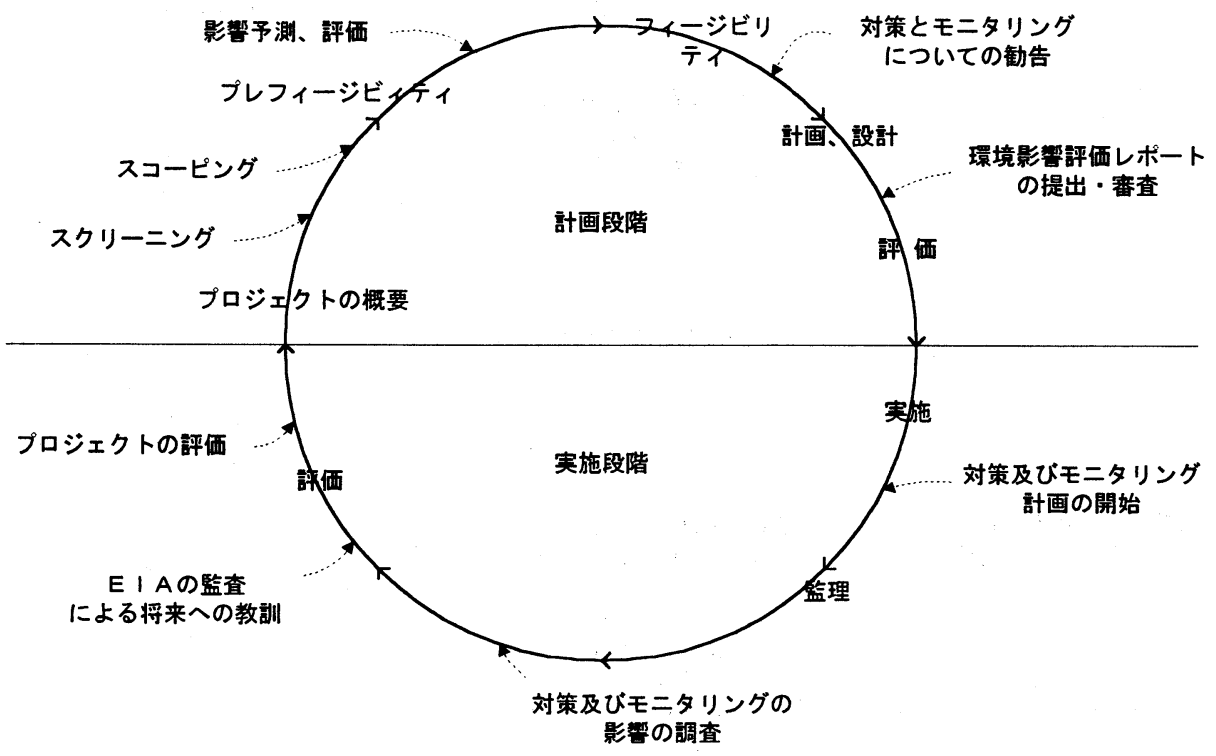

図一 5 開発プロジェクトの計画段階とそれらに伴う環境面の検討の対応

出典: Bd1iya, H. H. and A. 0. Suleiman, 1993. Country Report for Group Training Course in Environmental Impact Assessment

このような環境影響評価の段階的プロセスの最初にはスクリーニングが行われる。スクリ ーニングは、環境影響評価が必要であるかどうかを判断するステップであり、あらかじめり ストアップされている開発事業の種類、事業規模あるいは計画地域にあてはまるかどうかに よって判断される。これにより環境影響評価が必要とされるプロジェクトにあっては初期環 境影響評価が行われる。初期環境影響評価ではマレーシアなど多くの国でチェックリストを 用いた検討が行われており、影響があるかどうかが查定されている。その結果影響があると 判断された評価項目につき詳細な環境影響評価が実施される（図－6参照）。

このような開発途上国の環境影響評価の特徵は、以下のとおりである。

(1) 中国、マレーシア、パキスタン等にみられるように、詳細設計段階に入る前に環境影響 評価を行うなど、計画過程のかなり早い段階で環境影響評価が実施される。なお、国連 E S C A P、世界銀行、アジア開発銀行等の国際機関からも、一般に、フィージビリテ イ調查段階で環境影響評価を実施するよう勧告されている。

(2)開発途上国の法制度上、工事中や供用時に関して環境モニタリングや環境管理計画の策 定・実施を義務づける傾向がみられる。しかし、ほとんどの場合、モニタリング等の規 


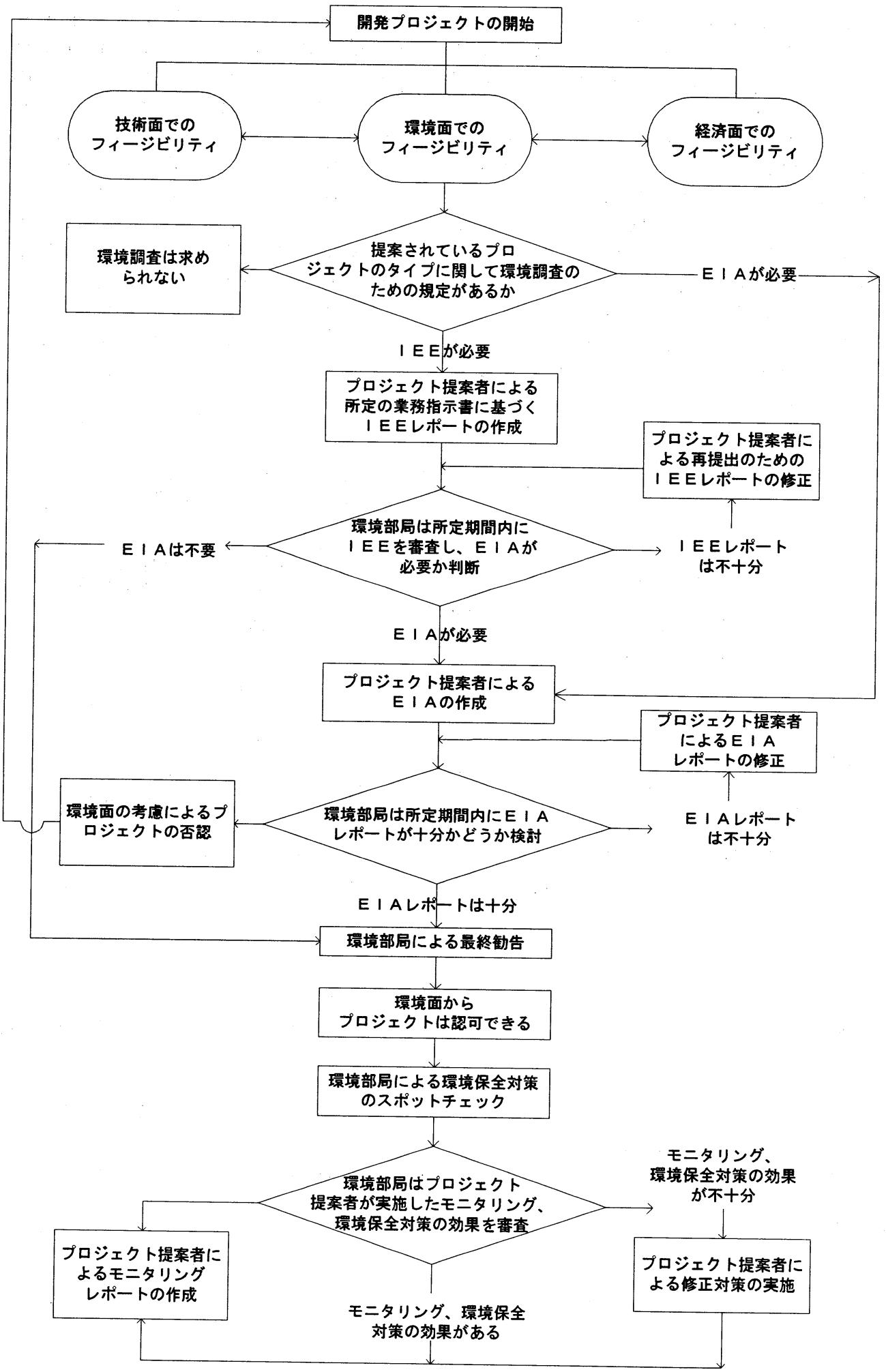

図一6開発途上国において一般的にみられる環境影響評価の作業フロー

出典 : Environmental Impact Assessment Guidelines for Planners and Decision Makers, - Environment and Development Series, 1985. ESCAP, UNITED NATIONS 
準とすべきバックグラウンドとしての水質や大気質等の現況が把握されていないことか ら、そのための調查を環境影響評価の実施中に行う必要がある。

(3)スクリーニングにより環境影響評価の実施を課せられたプロジェクトに関しては、その 評価対象とする環境項目をスコーピングによって抽出し、限られた情報をもとに短期間 のうちに環境影響を検討して計画内容に反映させる必要がある。

(4) 評価に際しては代替案との比較検討が要求されることもあるが、その際、計画内容の未 確定な部分や詳細な情報の不足などがある場合には、「現時点では不明」として議論を その後の検討段階まで保留することは可能である。

(5)環境影響評価において評価基準として用いるべき環境基準を定めていない国が多い。

(6)計画に対する民意の反映のため、環境影響評価制度のうえで、住民参加の場が重要視さ れることがある。

(7) 住民移転や漏出事故及び危険物取扱いに関するリスクアセスメントなど、わが国では計 画の大前提として環境アセスメントの実施に先立って確定している点や、事業者の責任 において措置されているような点が環境影響評価の段階で重要視されることが多い。

\section{6 。まとめ}

本研究により、開発途上国における環境影響評価、とくに港湾開発に伴う環境影響評価の現 状に関して以下の点が明らかとなった。

(1)開発途上国における環境影響評価制度は1980年代後半から急速に整備されつつある。

(2)開発途上国の港湾整備プロジェクトの約 8 割が、法律、行政措置等により環境影響評価 を実施している。

(3)港湾環境影響評価に際して重要となる環境項目は、人口稠密地域の港湾では水質污濁、 漏出事故、危険物の取扱い等であり、人口の希薄な地域の港湾では漏出事故、危険物の 取扱いのほかに、生態系及び社会的インパクトがあげられる。

(4) 開発途上国における環境影響評価は、計画を熟成させていくプロジェクトサイクルの各 段階において、スコーピング等により抽出された環境項目について影響の検討を行う。

\section{7.おわりに}

開発途上国の環境影響評価をめぐる状況は変化のさなかにある。 3 年間の調查研究を通し て得た情報も遠からず過去のものとなるであろうことが充分に予想される。開発途上国にお いて環境影響評価が適切に実施されるためには、環境法制度、環境影響評価ガイドライン及 び環境基準や排出基準等に関して今後とも情報収集に努める必要があろう。

\section{謝辞}

本調查研究の実施に際しては、（財）国際臨海開発研究センターに関倸者からなる委員会 (委員長堀江毅) を設置し、その助言や議論を参考とした。運輸省関係部局からは多々の 有益な助言を頂いた。また海外経済協力基金及び国際港湾協会からは、貴重な資料・情報の 提供を頂いた。これら関倸各位に対し深甚なる感謝の意を表する。さらに、アンケート調查、 ヒアリング調查に快く応じて下さった港湾管理者やわが国から派遣された港湾分野の専門家 の方々に厚く御礼申し上げる。

なお、本調查研究は、(財) 日本船舶振興会の補助金を受けて実施したものである。

参考文献: 図 -1

$$
\text { 表 }-1
$$

$$
\text { 図 }-2 、 3 、 4
$$

図 -5

図 -6
「地球白書 $1995-96$ 年」レスター・R・ブラウン

「平成 7 年度海外の港湾における環境配虑方策調查報告書」

(財) 国際臨海開発研究センター

「平成 5 年度海外の港湾における環境配慮方策調查報告書」

(財) 国際臨海開発研究センター

「平成 6 年度海外の港湾における環境配虐方策調查報告書」

(財) 国際臨海開発研究センタ-

Bdliya, H. H. and A. 0. Suleiman, 1993. Country Report for

Group Training Course in Environmental Impact Assessment

Environmental Impact Assessment Guidelines for Planners and Decision Makers, - Environment and Development Series, 1985. ESCAP, UNITED NATIONS 